[Lauder, H. (1992). Notes Towards a New Agenda for Policy-Making in Aotearoa/New Zealand. New Zealand Annual Review of Education, 1, 1-14]

\section{Notes Towards a New Agenda for Policy-Making in Aotearoa/New Zealand}

\section{HUGH LAUDER}

199 991 was not an auspicious year for the development and implementation of education policy. The assumptions that have guided educational policy making in Aotearoa/New Zealand since 1988 remained. Namely, that education has performed badly, so badly it is in need of radical overhaul and that the risks associated with such a revolutionary strategy are worth it, even at the expense of alienating parents and educationists. Such radical surgery is intended, among other things, to address the urgent issues of reducing the fiscal debt and of setting in place a system of education which will provide for the future economic needs of Aotearoa/New Zealand. Precisely what the future needs of the economy will be with respect to educated labour is a matter of debate.

These assumptions and related aims are worth considering in detail because they have led to a decisive shift in emphasis in the principles governing educational provision and opportunity. During this century two potentially conflicting principles have been used as the basis for the provision and opportunity. The first rests on the assumption that the talents and potentialities of all students should be the major focus in determining educational opportunities. The principle reflects a concern with meritocratic criteria for the selection and promotion of ability and asserts the primacy of national and community values over those relating to individual choice. The principle finds it expression in the idea of a comprehensive school which recruits from the widest spectrum of the population possible and which provides a high standard of resources for each student irrespective of their background or achievement. The comprehensive school should, in principle, obviate

\section{Hugh Lauder}

the problem of choice because all such schools should provide equal and wide-ranging opportunities for all their students. In contrast, the second principle emphasises the primacy of parental choice as the key determinant of educational opportunity. Choice, it is argued, can be translated into a motivating principle which not only lifts the performance of individual students, because they and their parents can choose the kind of education they want, but also the system as a whole; the sanctions and incentives created by choice through the market mechanism provide the spur to greater collective educational achievements. If the comprehensive school is the practical exemplar of the first principle, the private school is the exemplar of the second.

Until 1991 it can be argued that Fraser's dictum that educational opportunity should be concerned with the talents and potentialities of students, remained the dominant principle guiding New Zealand education although imperfectly realised and latterly threatened. Although the dominant principle, it co-existed alongside the principle of choice in that a small but influential private sector flourished. However in 1991 the relative influence of the two principles changed. During the year a range of educational policies was introduced which saw the wealth and social background of parents assuming greater significance in determining educational opportunity. It remains an open question as to whether this will create greater educational inequalities. However, the weight of evidence is such that the introduction of choice and competition into education must be considered an unwarranted risk. ${ }^{1}$

Choice can be a motivating factor and in an increasingly differentiated social world it can be and has been used as a lever for fostering the collective interests of particular ethnic groups. Choice, as Maori have demonstrated, does not have to be understood in an individualistic sense. ${ }^{2}$ But, as a general principle applied in an unequal context, that of a market society, educational choice is likely to be translated into a licence for unacceptable privilege (Brown \& Lauder, 1991).

What is less in question is that the introduction of targeted assistance and increased fees for tertiary students will mean that family wealth will assume far greater importance in determining access to tertiary education. This fundamental change in the underlying principle informing educational policy needs careful examination because it is 
unlikely to provide greater educational opportunities or a more highly skilled workforce. Most importantly of all, as we embark on 1992, it is unclear whether this new principle can sustain a nationally viable system of education.

\section{Has Education Performed Badly?}

Let us begin with the key underlying assumption. The claim that education has performed badly has provided the rationale for the radical restructuring of education but as claims go it is something of a moving target. Every time those who seek to take issue with it do so they find that its meaning has changed. As a political ploy this may be convenient but it hardly contributes to sound debate. That said, there are at least three senses in which the claim can be understood. Perhaps the most obvious is that educational standards have declined. However the notion of standards is itself a difficult one (Torrance, 1992). If international comparisons have any validity then New Zealand has clearly done quite well (Elley, 1991; Irving, 1991) with further good news to come in the middle of this year with respect to literacy. Of course, more evidence by way of recent international comparisons in the areas of maths and science is needed (and on its way) but the crucial point, surely, is that the record of education under the previous system did not warrant such wholesale restructuring. Moreover, while the debate on the cost of education relative to performance has not been of a high standard, the recent analysis by the New Zealand Council of Trade Unions (1992) does not suggest that education's past achievements have been expensive.

A further sense in which education can be said to have performed badly relates to the question of flexibility. Here there have been two kinds of claims made: that education was overly bureaucratic excluding parents from the educational process; and that education did not respond quickly enough to the demands for the development of a mass senior secondary and tertiary system. The former claim has substance. Few would deny that the school system, at least, was cumbersome in its decision-making processes and a source of frustration to teachers, principals and governors. The latter claim usually has two related elements to it: that school leavers have a low proportion of educational qualifications relative to other OECD countries and that the numbers of those gaining tertiary qualifications are accordingly low. If we assume for a moment that there is a connection between the quantity and quality of education, as those who have made this claim have done, then it is worth pointing out that there has been a major growth in retention rates, there has been a significant increase in the numbers achieving credentials and the levels at which they have been achieved, and there has been a substantial rise in the numbers attending tertiary education (NZCTU, 1992). Nevertheless, New Zealand has had an elite system in which large numbers of students were "cooled out" into the workforce without qualifications largely through the mechanism of the School Certificate exam. At the same time employers enticed students into the labour market, perhaps prematurely. The irony here is that it is not educationists but employers and politicians who ensured the anachronistic School Certificate examination remained. And, indeed, there are many on the Right who are still fighting tooth and nail for its retention.

The final sense in which "education" is said to have performed badly is in relation to educational inequalities. Certainly major inequalities persist with respect to Maori, women and working class students. These inequalities represent the hidden injuries of class, patriarchal and racist structures; they constitute a loss of potential and opportunity for the individual and a major wastage of talent in a national economic sense. However, few can believe a system of education increasingly based on the wealth and social background of parents is likely to do anything but reinforce these inequalities. Indeed the fact that there has been a retreat under this government from the notion of equality of opportunity to that of the more nebulous "equity" suggests that the "reforms" of 1991 were not intended to address the issue of equality of opportunity.

However, the question of equality of opportunity raises a further issue regarding the claim that education has performed badly. Educational institutions do not work in a vacuum, they work within a specific social and economic context that has a direct bearing on educational outcomes. One of the clearest findings from over thirty years of international research effort, including research in New Zealand, suggests that the social background of children has a major influence on their educational performance. The myth, perpetrated by the claim that education has performed badly, is that educational outcomes are solely attributable to what goes on in educational 
institutions. The myth has an ideological function, it is a way of identifying scapegoats and of diverting attention away from the overall effects of government, social and economic policy. This is not to suggest that questions should not be raised about how well educational institutions are performing but it is to insist that such questions be asked in cognisance of the effects on education of the wider social and economic context.

Let us draw together the threads of the discussion so far. Clearly there are ways in which it is desirable to improve education in Aotearoa/New Zealand. In particular it needs to (i) find ways to become more flexible with respect to decision-making and community participation; (ii) establish more effective ways of mitigating economic and social inequalities; (iii) move from an elite to a quality mass upper secondary and tertiary system of education. The crucial issues turn on whether these improvements can be made while maintaining existing high standards of education and preserving the primacy of the principle that educational opportunities should be determined by the talents and potentials of all students. These are vital issues and ones to which I shall return.

\section{The Costs of the Government's High Risk Low Trust Strategy}

In 1991 the National Government operated a high risk low trust strategy in education. High risk, low trust strategies are usually a sign of political and social breakdown because of their high probability of failure. More specifically, they are introduced, typically, in a political context where an elite seeks to impose its will on the majority. In New Zealand the inspiration for such a strategy comes from the New Right notion of provider capture or vested interests, a notion associated more with an elected dictatorship than with participatory democracy (Lauder, 1991). The fundamental assumption underlying the idea of vested interests is that those directly involved in, for example, education (parents, teachers and students) cannot rise above a consideration of their short term interests and therefore should be excluded from deliberations about the overall structure of education. Accordingly, when in 1991 the groups set up to review education (yet again) were announced, parents and teachers were excluded. The consequence of such a strategy is the risk of low morale amongst those most directly involved in education - and, unworkable policy. This, in turn, raises a question about the sacrifices in educational quality the government is prepared to make in order to implement a blueprint of dubious pedigree.

The question of low morale amongst educationists and its impact on students should not be underestimated. Let us not forget that teachers in the primary and secondary sector have had to deal with three different models of decentralisation in four years. The Picot (1988), Tomorrow's Schools (1988) and Sexton (1990) Reports provided three different models for educational devolution with quite different effects and likely outcomes. From the perspective of the school these sudden changes have imposed conflicting demands and considerable stress. Of course, the change from one model to another represents moments in the struggle over the ownership of the reforms, a struggle created by the failure of successive governments to seek, far less achieve, a consensus. Part of this struggle has centred on a constant barrage of criticism of teachers and the education system: interest groups such as the Business Roundtable and the Education Forum, Government agencies such as the Treasury and the Government itself, have all sought to show that self-interest and low educational achievement have been predominant characteristics of the state educational system. It has made an unedifying spectacle, especially since the major reports released by these agencies have themselves been characterised by a lack of well considered argument ${ }^{3}$ and a total blindness to the criticisms of their own favoured market system of education. More alarming have been the risks advocates of marketisation have been prepared to take to experiment on such a large scale. One consequence risked by the attack on education is the sapping of teacher morale and the withdrawal of goodwill. Both will do great damage to the quality of education in this country. The education system, like the health system, depends on goodwill. It is integral to the successful day to day interactions between teachers and students - how can a teacher communicate the necessary optimism and commitment under the present circumstances? - yet the critics of the education system choose to ignore its significance, the consequence of espousing a theory of motivation which asserts that people only act out of self-interest.

Risks of a different order have also been taken in the tertiary sector where the burden of assistance to students has been shifted decisively onto the students themselves and their families. While students sought to enrol in tertiary institutions in unprecedented numbers in 1992, it 
remains an open question as to whether they will be able to find the resources to complete the courses they have begun. This shift in the burden of assistance was meant to be accompanied by a supporting loan scheme. It was hurried in conception, arrived too late for many, and remains unattractive to most. The risk is that if students find, over time, that they cannot afford tertiary education, the government's proclaimed strategy of increasing the number of tertiary qualified graduates will fail. The problems of a poorly realised set of policy strategies in the tertiary sector were further exemplified by the contradictions they created in terms of the government's own stated aims. The introduction of market principles into the tertiary sector led, in the budget document, to higher charges for science and engineering courses than for arts courses at a time when it has been argued more scientists are needed. The underlying rationale for these higher charges was that the science graduates would gain a higher return for their credential - this at a time when positions in science are fast disappearing. A similar but far more serious irony emerged with the targeting of student assistance for it was accompanied by demands so intrusive of individual freedom and privacy as to be unacceptable - this from a government which has championed the cause of individual freedom.

These examples are, of course, but symptoms of the far-reaching malaise that governs educational policy-making in New Zealand. We need, therefore, to go beyond the symptoms to the underlying causes and the issues they have highlighted? Here we need to look at the effects of the change in emphasis in the principles determining educational opportunities and raise the question, can the desired improvements be made while remaining faithful to Fraser's principle and, in such a way as to achieve a new settlement in education? To do so would be to map out a new agenda in educational policy-making on the basis of consensus and incrementalism rather than confrontation and revolutionary change.

\section{Notes Towards A New Agenda for Education}

\section{The threat to a national system of education}

To gain a more adequate grasp of why educational debate and policymaking has taken its present form we need to look at what is happening in Aotearoa/New Zealand within a wider global context. Two apparently contradictory forces appear to be at work. On the one hand, a global economy has developed rapidly and to the point where the idea of a national economy is now in question (Reich, 1991). On the other hand, ethnic and national rights are being reasserted: the secession movements of "minorities" has become a leitmotif of the (post-?) modern world. But it is not only ethnic and national minorities that are seceding, the conditions have been laid for transnational capitalists and the highly educated middle class who are part of a global labour market also to secede from national systems of education, health and welfare. Their high income and geographic mobility means they have less allegiance to a national system of education and a greater concern to buy "quality" through private education. ${ }^{4}$

The conditions for such "class" secession have "coincided" with the rise of a New Right ideology which asserts the primacy of individual choice over national interest and elevates the market over the state as the panacea for our ills. For the New Right, the threat to economic nationhood is to be answered by disestablishing the nation: the individual is considered the primary economic unit. The problem is that for the majority of New Zealanders, who do not have access to global labour markets, the integrity of a viable national economic system and of a viable national education system are vital to their life chances and those of their children. However the further bind that the majority of New Zealanders find themselves in is that the economic and social policies of the past seven years have created the conditions whereby this country is now part of a global auction to attract investment and highly educated labour. In this auction low income taxes, low company taxes and low wages for the less educated are the key to "winning" the auction. ${ }^{5}$ The outcome of this process, inevitably, is that there will be less money for the financing of an adequate, national state system of education. The overall effect for education of the global economic changes has been, therefore, to create the structural conditions whereby the pupils and the financial support of the professional middle classes are withdrawn from the state sector: a situation which must inevitably threaten the idea of a national system of education.

National systems of education have been a key factor in the development of nations. It is, then, not surprising that at a time when our economic nationhood is threatened so should our national system of education be threatened. A fully marketised system of education as 
envisaged by Sexton would mark the end of a national system of education. Under his system wide disparities in the nature and quality of schooling could be expected. As it stands, the introduction of bulk funding of teachers' salaries now seems inevitable and if this is combined with the "freedom" of schools to determine wages and work conditions, a major plank of a national system of education will have been removed. ${ }^{6}$ What is then left of a national system if there is not to be roughly comparable funding for all schools, comparable class sizes and a comparable quality of teachers but the thin blue line of Dr Smith's national curriculum and achievement initiatives. But this, itself, may be jeopardised if, as now seems possible, bulk funding is introduced at the same time as the national curriculum and achievement initiatives. If this does occur, and it would be par for the course given current policy practice, we will arrive at the Sexton system by default because the "serendipity, ad hocery and chaos" (Ball \& Bowe, 1992) which have marked the introduction of the national curriculum in England, will be experienced here. The irony is that from all accounts, the Minister of Education has listened to sound advice on the curriculum and achievement initiatives and that they promise to be the most educationally defensible policies introduced by this government.

The secession thesis advanced here begins to explain why, in the absence of sound educational reasons, the education system has endured such massive restructuring. The restructuring has been determined by a combination of global economic and political change, which has created the conditions for a fundamental shift in the power relationships between the state and the education system, and an economic crisis which has provoked attempts to get more "quality" for less money in education. The link between the two is a New Right ideology which attends to both the political interests thrown up by changes in the global economy and the cost cutting demands provoked by the economic crisis. ${ }^{7}$ It is precisely under such conditions that a high risk low trust strategy of change is likely to be adopted.

\section{Towards a new settlement in education}

In the space allotted it is not possible to discuss what could constitute a new settlement in education for all the educational sectors. In the primary and secondary sectors, however, a settlement, which seeks to maintain a national system of education according to Fraser's principle, is at hand. The outcome of the Tomorrow's Schools reforms (rather than the document itself) went a long way to meeting the problem of bureaucratic inflexibility and the need for greater parental involvement ${ }^{8}$ while maintaining the conditions for an equitable national system of education. The equity demands built into the system, the national award structure and the structuring of "choice" provided the basis for what is an achievable settlement. ${ }^{9}$ Most educationists and parents appear to have accepted the policies which emerged from Tomorrow's Schools for it constituted a unique and interesting attempt at balancing the contemporary demands of community participation and national interest.

On the basis of such a settlement, educational policy would then proceed by what could be called limited critical interventions (LCIs). A good example of such an LCI is the Reading Recovery programme. It has a clear focus in terms of aim, clear limits in terms of budget expenditure, and it allows for a high level of professional autonomy and discretion. And, given these parameters, it has the potential for being soundly evaluated. Another such example is the development of the Kura Kaupapa Maori schools. There are several areas which are candidates for LCIs and the task for educational policy is to identify those areas, determine their priority and then develop the appropriate initiative. By current standards such policies are likely to be unspectacular and relatively uncontroversial but far more effective than the what has passed for educational policy in recent years.

Of course the change in policy strategy from what might be called permanent revolution to LCIs, would require a fundamental change in New Zealand politics from a politics of exclusion and secession to one of inclusion. It would also require a major change in the nature and quality of advice that is currently afforded governments by the Treasury and State Services Commission. ${ }^{10}$ The question will arise as to how practical a return to Fraser's principle is given the changes in the global political economy sketched above. The answer is to look at the examples of those European societies where a principle of consensus and social solidarity remains the key organising feature of both economy and society. As Esping-Andersen (1990) has noted in such societies, the role of the welfare state is not in question in the way it is in New Zealand, and such societies appear to be far more economically successful that Anglophone dominated countries like New Zealand in which the New Right has become so influential. 
Notes

1 There are many elements to the marketisation non-marketisation debate, although the key focus appears to be the impact of marketisation on effective schooling. The only research that provides any rationale for a marketised approach is that of Chubb \& Moe (1990). They show that the governance structures of schools has an impact on school outcomes. But the impact is slight, it accounts for some 5 per cent of the difference between schools. Then again, it is unclear whether the politics of the New Zealand school system is sufficiently comparable to the schools studied by Chubb and Moe for their findings to be remotely relevant to this country. More importantly, there is a large body of research including that undertaken in New Zealand (Lauder \& Hughes, 1991) which suggests that parental background, prior achievement and the social mix of pupils are key factors in determining school outcomes and that consequently the better balanced the social class intakes of schools, the higher will be overall achievement. If we assume that the introduction of choice and competition will lead to a polarisation of school intakes according to social and ethnic background, we can also assume that, overall, there will be a decline in standards (Lauder, 1991). Interestingly, Chubb \& Moe found the same variables to be significant, but they chose to ignore their importance.

2 See for example the critique of the Sexton Report with respect to Maori by Marshall, Peters and Smith (1991). See also Snook (1990). Snook's interesting paper explores the basis on which the development of a different system of education for Maori could be justified. His explorations do not, of course, include individual choice.

3 For example, the Sexton Report failed to address the evidence with respect to effective schooling altogether and didn't therefore consider what the likely impact of marketising schools would be on their effectiveness. The Education Forum's latest publication, Better Teachers for Better Learning (1992) makes some attempt to deal with these issues but its use of the research literature to underpin its arguments, especially the use of Chubb \& Moe (1990), is uncritical and fails to place their controversial findings into the wider context of the literature on effective schools. There have been several substantial critiques of Treasury documents on education.

4 The reason why private schooling is perceived to guarantee quality has less to do with the education provided and more to do with the nature of the students they attract - students, by and large, recruited from the highly educated middle class. See Lauder (1991) for an elaboration of this point. For those of the educated professional middle class who do not send their children to private schools, the new "choice" regime allows them to gain a greater access to elite single sex state schools; it also enables such schools to manage their intake to ensure it is of the "appropriate" kind.

5 The European social charter is a clear attempt at putting a floor or "reserve price" on this auction. See Deakin (1990) and Walsh (1992) for an understanding of how elevated the "floor" is in relation to the social and economic conditions confronted by New Zealand workers.

6 There is good evidence from the UK (Glennerster \& Low, 1990) and the USA (Reich, 1991) to suggest that once central government withdraws from a commitment to equality of funding, disparities in funding develop. In the USA they appear much wider than, on average, in the UK.

7 See Gordon in this journal for an understanding of the role of the state in this context.

8 Parental involvement is a key notion in Tomorrow's Schools, quite rightly since the greater the involvement of parents in their children's schooling, the more successful the children are likely to be. Interestingly, the New Right considers that the parent's role in school governance should be downgraded presumably on the grounds that having parents on Boards of Trustees muddies the theoretical waters in which a tight distinction is drawn between consumers and producers, in which case of course, the model could not be justified on educational grounds. However, the more likely reason for the New Right wanting to see parents eased out of the governance role is that parents have expressed a reluctance to be involved in industrial matters which makes the imposition of bulk funding problematic. The solution is to remove the problem, i.e., parents [sic]. Parents, however, are quite right to reject involvement in industrial matters since these may interfere with their crucial educational partnership with teachers. Both Sexton (1990) and more recently Kerr (1992) have suggested the role of parents should be downgraded in school governance matters.

9 More work would need to be done in balancing individual choice of school with the national interest in high levels of education for all students. This could be done by asking parents to list their preferences for two or three schools with a zone but with the right reserved by the government to re-order preferences to maintain schools with wellbalanced ability and social class mixes. 
10 An example of the kind of sophisticated work the Treasury ought to be attempting is Glennerster \& Low's (1990) paper on the economics of education.

\section{References}

Ball, S. \& Bowe, R. "Subject departments and the "implementation" of national curriculum policy: an overview of the issues" Journal of Curriculum Studies, 24, 1992, pp. 97-115

Brown, P. \& Lauder, H. "Education, Economy \& Social Change" International Studies in the Sociology of Education, 8, 1991, pp. 3-25.

Chubb, J. \& Moe, T. Politics, Markets and America's Schools. Washington, The Brookings Institution, 1990.

Deakin, S. "The Floor of Rights in European Labour Law" New Zealand Journal of Industrial Relations, 15, 1990, pp. 219-240.

Elley, W. How Well Do New Zealand Students Achieve by International Standards? Christchurch, Education Department, University of Canterbury, 1991.

Esping-Andersen, G. Three worlds of welfare capitalism. Cambridge, Polity Press, 1990.

Irving, J. The Monitoring of Academic Standards in the Basic Subjects in New Zealand Schools vis-a-vis New Zealand's International Competitors and Major Trading Partners. Wellington, Ministry of Education, 1991.

Kerr, R. "Opinion", Metro. Auckland, Australian Consolidated Press (NZ) Ltd, 1992.

Lange, D. Tomorrow's Schools: The Reforms of Education Administration in New Zealand. Wellington: Ministry of Education, 1988.

Lauder, H. "Education, Democracy and the Economy" British Journal of Sociology of Education, Vol. 12, No. 4, 1991.

Lauder, H. \& Hughes, D. "Social Inequalities and Differences in School Outcomes", New Zealand Journal of Educational Studies, Vol. 25, No. 1, 1991.

Marshall, J., Peters, M. \& Smith, C. "The Business Roundtable and the Privatisation of Education: Individualism and the Attack on Maori" Delta Studies in Education No. 1, 1991.

NZ Education Forum: Better Teachers for Better Learning, 1992.

NZCTU Education and Economic Performance. A submission paper prepared for presentation to the government, 1992.

Picot, B. et al. Administering for Excellence: Effective Administration in Education: Report of the Taskforce to Review Education Administration. Wellington, Ministry of Education, 1988

Reich, R. The Work of Nations. London, Simon \& Schuster, 1991.
Sexton, S. A Report Commissioned by the New Zealand Business Roundtable on New Zealand Schools and Current Reforms. Wellington, Business Roundtable, 1990.

Snook, I. Democracy and Equality in a Bicultural Society. Paper presented to the NZARE Conference, Auckland, 1990.

Torrance, H. "Educational Assessment and Educational Standards: Towards an Alternative View of Quality" in Brown P. \& Lauder, H. (Eds.), Education for Economic Survival. London, Routledge, 1992.

Walsh, P. 'The Employment Contracts Act', in Boston, J. \& Dalziel, P. The Decent Society. Auckland, Oxford University Press, 1992.

\section{The author}

Hugh Lauder is Professor of Education at Victoria University. He has coedited Education: In Search of a Future (Falmer Press, 1988) (with Phillip Brown); Towards Successful Schooling (Falmer Press, 1990) (with Cathy Wylie); Education for Economic Survival (Routledge, 1992) (with Phillip Brown), and published many papers on educational inequality and on the economics of education. 